\title{
Surviving Modernity Through Magic: A Participatory Study on Pekalongan Sintren Performance
}

\author{
(Bertahan dengan Unsur Magis di Era Modern: \\ Studi Partisipatoris Pertunjukan Sintren Pekalongan)
}

\author{
Ratna Asmarani \\ Faculty of Humanities, Diponegoro University \\ Jl. Prof. Soedarto, S.H., Tembalang, Semarang 50275 \\ Tel.: +62 (24) 76480619 \\ Surel: ratna_asmarani@yahoo.com.
}

Diterima: 10 Maret 2019 Direvisi: 11 November 2019 Disetujui: 21 Desember 2019

\begin{abstract}
Abstrak
Penelitian ini bertujuan untuk menganalisis bagaimana sihir dilakukan di Sintren dan strategi bertahan hidup apa yang diterapkan oleh para pemainnya di era modern. Sintren adalah seni rakyat Pekalongan yang unik yang dilakukan oleh sebuah kelompok seni daerah yang disebut Kudo Bekso Utomo dari Desa Pringsurat, Kecamatan Kajen, Pekalongan pada tanggal 23 Juni 2018 selama festival Syawalan di Desa Linggo Asri, Pekalongan, Jawa Tengah, Indonesia. Untuk mencapai tujuan ini, peneliti menggunakan metode kualitatif. Data dikumpulkan dengan observasi partisipatif dan wawancara dengan penari Sintren, dukun Sintren, dan penonton Sintren. Selanjutnya, data dianalisis dengan konsep Performa oleh Goffman bersama dengan konsep "sihir" dan "trik" oleh O'Connor. Studi ini menemukan bahwa seni rakyat Sintren adalah pertunjukan unik yang bukan tipuan, tetapi penuh keajaiban. Selain itu, penelitian ini juga mengungkapkan bahwa Kudo Bekso Utomo mampu mempertahankan performa tradisional ini dengan menerapkan strategi ekonomi, seperti menggunakan kostum/alat pementasan yang lebih sederhana, selalu melakukan pementasan di setiap acara, baik secara resmi diundang maupun tidak, serta berusaha menghadirkan penari nonperawan. Strategi-strategi ini bahkan dapat diadopsi atau diadaptasi oleh kelompok seni regional lain untuk menghadapi modernitas.
\end{abstract}

Kata kunci: kesenian rakyat, kesurupan, pertunjukan, Sintren Pekalongan, suasana magis

\begin{abstract}
This study aims to analyze how magic is performed in Sintren and what survival strategies are applied by its performers in the modern era. Sintren is a unique folk art of Pekalongan performed by a regional arts group called Kudo Bekso Utomo from Pringsurat village, Kajen sub-district, Pekalongan on June 23rd, 2018 during the Syawalan festivals in Linggo Asri village, Pekalongan, Central Java, Indonesia. To achieve this goal, the researcher uses qualitative method. Data are collected by participatory observation and interview with the Sintren dancers, the Sintren shamans, and the Sintren audiences. Furthermore, the data are analyzed by the concept of performance by Goffman together with the concept of "magic" and "trick" by O'Connor. This study finds that Sintren folk art is a unique performance which is not a trick, but full of magic. Besides, this study also reveals that Kudo Bekso Utomo survives to maintain this traditional performance by applying economic strategies, such as using simpler costumes/performance tools, always conducting performance in every event whether formally invited or not, as well as trying to present non-virgin dancer. These strategies even can be adopted or adapted by other regional arts groups to cope modernity
\end{abstract}

Keywords: folk art, magical atmosphere, Pekalongan Sintren, performance, trance

\section{INTRODUCTION}

Belonging to the folk art, Sintren is popular along the north-coast areas of Java such as Indramayu, Cirebon, Majalengka, Jatibarang, Brebes, Pemalang, Banyumas, and Pekalongan. This paper particularly focusses on Pekalongan Sintren performance especially about its magical atmosphere and its strategies to survive in the modern era tending to push aside traditional performance. 
The root of Pekalongan Sintren is the folklore concerning the unhappy love story between a young man named Sulandono and a young woman named Sulasih. Sulandono's father, Ki Baurekso who was a very prominent person, opposed the love between his son with Sulasih, a beautiful girl from Kalisalak village. Sulandono's mother, Dewi Rantamsari, tried to help these broken-hearted lovers. She gave her son, Sulandono, a handkerchief as a means to meet Sulasih magically. She also asked him to meditate in an isolated place. Dewi Rantamsari also advised Sulasih to become a dancer and to dance in annual earth offering ritual to meet her lover. While Sulasih was dancing in a trance guided by the charm of the nymph, Sulandono would come and he would throw the handkerchief to Sulasih (Ribkha n.d.; Asyari 2017). In short, it is believed that every Sintren dancer will get the charm of the nymph while dancing in trance. Meanwhile, the word sintren is a combination of the word si which means 'someone/she' and tren which means 'princess/nymph.' Thus, the word sintren means 'the dancing female is a princess/nymph.' In other words, those who is dancing is not the real person but the spirit/nymph entering the body of the female dancer ("Rahasia Mistis Tari Sintren" 2015).

There have been several articles written about Sintren, whether focusing on Sintren Pekalongan or Sintren from other areas along the north coast of Java. For example an internet article entitled "Mencari Jejak Sintren, Kesenian Rakyat Asli Pekalongan yang Telah Punah" ("Looking for Sintren's Traces, the Almost-Extinct Folk Art of Pekalongan") which talks about the attempt to revive the folk art by the locals (Bro 2016) and another internet article entitled "Gemulai Sintren di Pesisir Pekalongan" ("The Swaying Sintren in Pekalongan Coast") talks about the history and performance of Sintren Pekalongan" (Asdhiana 2014). A journal article entitled "Kesenian Sintren sebagai Kearifan Lokal Ditinjau dari Metafisika Anton Bakker" ("Sintren Art as a Local Wisdom Viewed from Anton Baker's Metaphysics") focuses on the local wisdom of the Pekalongan Sintren Art (Aditama 2016). Thus, it can be concluded that there is still a gap to analyze the magical elements in Pekalongan Sintren, particularly performed by the regional arts group Kudo Bekso Utomo, and its strategies to survive even though it has limited facilities while facing the modern era caring so little to the traditional art performance.

In order to support the analysis on Pekalongan Sintren as a magical performance, several concepts are presented. The first one is the concept of performance from Goffman. He states that,

A 'performance' may be defined as all the activity of a given participant on a given occasion which serves to influence in any way any of the other participants. Taking a particular participant and his performance as a basic point of reference, we may refer to those who contribute the other performances as the audience, observers, or co-participants (Goffman 1956:8).

From Goffman's concept, there are certain points that must be noted; namely, there is an intention to influence the spectator by the performer and there are spectators that just see the performance, the critical spectators, and the participative spectators.

Still associated with 'performance' Goffman introduces the term "front" referring to the paraphernalia needed for the performance which includes what he calls "setting" or the articles needed to create a certain scene (Goffman 1956: 13). Goffman also mentions "personal front" referring to mien and gestures of the performer. This "personal front" is further divided into "appearance" and "manner" by Goffman (Goffman 1956:14-15). Goffman emphasizes that:

the performer can be fully taken in by his own act; he can be sincerely convinced that the impression of reality which he stages is the real reality. When his audience is also convinced in this way about the show he puts on-and this seems to be the typical case- 
then for the moment, anyway, only the sociologist or the socially disgruntled will have any doubts about the 'realness' of what is presented (Goffman 1956:10).

In other words, Goffman indicates that the performer can totally believe in what he is constructing in the performance and at the same time can make the audience feel assured that what they see is real. If so, according to Goffman, only the very critical observer can question the "realness" of the happening.

Still talking about 'performance', Ben-Amos says that 'performance' is "In folklore, a mode of presentation in which a party or parties utilize conventional artistic techniques to stage actions for others" (Ben-Amos 1997:630). Further, Ben-Amos states that "Theatricality, however minute and fleeting, has become a key quality in the folklore performance [...] verbal, visual, musical, and mimetic symbolic forms-as the substance of performance" (Ben-Amos 1997:631-632). Staginess, or constructed event, is the basic factor in performance that may consist of various forms.

The second concept to support the discussion is the concept of "magic" and "trick." The different meaning between the two concepts is important to note to support the notion that Sintren is not a trick, however sophisticated, but a magic traditional performance. According to O'Connor: "Magic, as it is diversely represented in the cultures of the world, relies upon belief in a universal "sympathy" between all existent things, natural and supernatural, creating a web of meaningful association linking magical knowledge with magical acts" (O'Connor 1997:519). In other words, O'Connor emphasizes that magic in whatever form indicates the harmony of "natural and supernatural." O'Connor also quotes James Frazer's two kinds of magic: "(1) homeopathic magic, that is, magic that operates through the indirect action of similarity, like engendering like, and (2) contagious magic, that is, magic that operates through the direct action of contact influencing a desired outcome" (O'Connor 1997:519). Magic also means "the use of rituals or actions, especially based on supernatural or occult knowledge, to manipulate or obtain information about the natural world" ("Magic vs Trick - What's the difference?" n.d.). In other words, for magic in this sense it is believed that there is always an involvement of spiritual being.

Another meaning that should be understood to support the analysis in this paper is about the term "trick." A trick is "something designed to fool or swindle" ("Magic vs Trick - What's the difference?" n.d.). Google explains that the word "trick" as a noun means "a cunning or skillful act or scheme intended to deceive or outwit someone" and as a verb it means "deceive or outwit (someone) by being cunning or skillful" and as an adjective it means "intended or used to deceive or mystify, or to create an illusion" ("Trick" n.d.). A term related to trick is a "magic-trick" in which the dictionary meaning is "A remarkable act carried out purportedly by magical means but actually by trickery or illusion, generally as a form of entertainment" ("magic-trick" n.d.). Based on those explanations, "trick" does not involve spiritual being. "Trick" is a deliberate action done sophisticatedly, sometimes with the help of certain apparatus, with the purpose to fool someone whether to get certain benefit or to entertain.

The fourth concept to support the discussion is about "shaman" and "trance." There are so many definitions of these two words, however in this paper the nearly suitable definitions for analysis will be presented. "Shaman" is:

One who can interact and mediate with the spirit world on behalf of their community, usually by ecstatic trance techniques (That is their spirit/soul leaves their physical body in order to travel to a world of pure spirit rather than physical matter) for the purposes of 
divination, information gathering, healing and to receive wisdom. Believed to come from the Tungus word "saman" meaning (very roughly) holder of knowledge (Kynth 2007).

Shaman and trance, whatever the relationship, cannot be separated. Generally, trance is "an example of an 'altered state of consciousness' (ASC for short), that is, being in a state of mind that is different from the ordinary waking one [...] Dreaming, extreme exhaustion, drunkenness, druggedness, meditation, spirit possession [....]" (Jones n.d.). Shaman and trance are also often associated with the involvement of supranatural thing called spirit. Pentikäinen says that "There is also a belief in helping spirits who assist the shaman. In addition, the shaman achieves his or her ends by using ritual paraphernalia, which vary culturally: drum, dress, bag, mask, and so forth” (Pentikäinen 1997:766).

However, all the above concepts, especially about magic, shaman, trance, and the paraphernalia needs specific adjustment due to the different context. The context of Pekalongan Sintren performance, including the human and non-human supporting it, is not exactly the same as the context producing the concepts of magic, shaman, trance, and the paraphernalia quoted above.

Another interesting point in discussing the existence of Pekalongan Sintren performance is its survival strategy in facing the modern world. Inglehart and Baker clearly indicate that modern society with its economic drive tends to estrange the traditional performance, however the traditional arts tend to be "persistent" (Baker and Inglehart 2000:19). This warning has been realized by those involved in traditional arts. Irianto mentions that traditional art performance uses adaptive strategy through "differences of style and variation" (Irianto 2017:90). Mulyono, leader of Ngesti Pandowo, Javanese theatrical performance, faces two bitter facts in preserving his traditional group. The public interest on the traditional performance is decreasing and the traditional performance does not get yearly financial support from the Central Java Province government anymore. However, there is an urgent appeal from the provincial government that the school children should watch the traditional performance to introduce the traditional performance to the young students. To keep surviving, he decides to shorten the performance duration into one hour only and adds new theatrical characters such as animals and giants to interest the school children (Aldila 2017). A group of shadow puppet with Catur Benyek Kuncoro as the puppeteer uses different strategy to survive. This traditional group combines the traditional music with hip hop music. Besides, the topics of the performance are about current issues to interest the public to come watching its performance (Saputra 2015).

Based on the theoretical perspectives supporting the discussion, there are two purposes in writing this paper. The first is to show and discuss how the magical element as the essence of the Sintren performance is still kept in the midst of financial hardship. The second is to discuss the survival strategy applied by this traditional performance, based on the direct observation and conversation with the Sintren shaman. The two purposes are discussed in an intertwined way since the effort to keep the magical element and to survive cannot be separated.

\section{METHOD}

The object of the field research was the Sintren performance done by a regional arts group called Kudo Bekso Utomo from Pringsurat village, Kajen subdistrict, Pekalongan. The performance was staged after the tradition of Giant Cone Megono and the festival of the village harvests. The data of Pekalongan Sintren was taken on June $23^{\text {rd }}, 2018$ in Linggo Asri village, Pekalongan, during the Syawalan festivals. The Sintren dancer was a young girl named Anisa who was always accompanied by two female adults named Sunipah and Fitri. The Sintren shaman or Pawang Sintren was Tardi and his assistant was Solikhin. In Sintren performance, the Sintren shaman is not the one who is in trance or entered by spirit, but he is the one who makes the Sintren dancer in trance with his 
incantation. Thus, the meaning and function of shaman in Pekalongan Sintren is different from that of the Western concept defined in the previous part.

The field research used follows Dundes' two stages in doing folklore research: the identification and the interpretation. The first stage, identification stage, is objective and empirical in nature while the second stage, the interpretation stage, is subjective and speculative in nature (Dundes 1965:1-3 in Bronner 2007:70). Dundes' two stages of folklore research is supported by library research method and by interviewing the relevant informants. Another method used is Participant-Observation Method. McCormick states that this kind of method is "typically employed in conducting field research [...] requiring fieldworkers to be both participants in a target community and objective observers who translated their participant experience into a formalized summary" (McCormick 1997:628).

In the field research, the writer not only observed directly the Sintren performance but the writer also involved in the performance by participating in tying both hands of the Sintren dancer before she was placed in a bamboo chicken cage for her next changing of costume. The writer also interviewed the Sintren dancer before the performance, the Sintren shaman, and the audience. The writer was also involved in the process of saweran or giving money to the dancer. Important images were taken to support the discussion on magical charms of the Pekalongan Sintren performance.

\section{RESULT AND DISCUSSION}

Kudo Bekso Utomo, the regional arts group performing the Pekalongan Sintren, has established since 1972. Based on the interview with the shaman, an amazing fact was discovered. Usually, based on tradition and the folklore obeyed by all the Sintren performance along the north coast of Java, the Sintren dancer has to be a young virgin female. However, the Sintren dancer of Kudo Bekso Utomo, according to the shaman, could be a married woman. This breakthrough might be triggered by the difficulty of finding a young virgin female to become a Sintren dancer since the young virgin females are mostly not interested to be dancers in a traditional and magical performance. However, the dancer of the Pekalongan Sintren show on June 23rd, 2018 in Linggo Asri village, which is the object of the observation and research, was still a very young virgin female. Although the writer did not witness the non-virgin Sintren dancer in action, the information from the shaman of Kudo Bekso Utomo can be used as an indication of a strategic survival system of the group in facing the hardship to find the young virgin dancer of the Sintren performance in the modern era.

\section{Sintren as a Folk Art: Three Phases}

Pekalongan Sintren folk art based on the performance done by Kudo Bekso Utomo on June 23rd, 2018 in Linggo Asri village, Pekalongan, could be divided into three phases. The first phase was the gamelan music to invite audience to gather. The second phase was the preparation by the Sintren shaman and his assistant while the Sintren dancer accompanied by four female escort dancers were dancing while circling the arena. The third phase was the essence of the Pekalongan Sintren performance, that is, the Sintren dancer was in action in which she, in a trance, changed into three different costumes inside the small bamboo chicken cage while both of her hands were tied with a rope.

\section{The First Phase of Sintren as a Folk Art}

The first phase of Sintren was like a warming-up phase. It was dominated by the gamelan music. The gamelan was set up in a little bit higher stage. The gamelan was luring the audience to come nearer so that they would create a circular arena. This informal arena was an open-air show. 


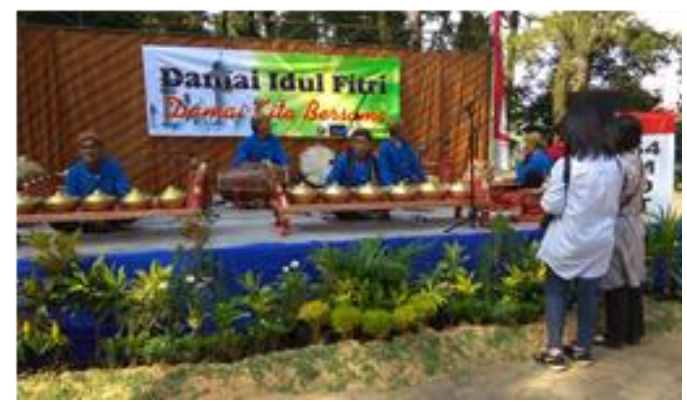

Image 1. the Gamelan and the crew on a stage

(Team document: Linggo Asri village, Pekalongan, June 23rd, 2018)

\section{The Second Phase of Sintren as a Folk Art}

The second phase of Sintren was the preparatory phase. At this stage the Sintren shaman and his assistant were preparing the show by placing the burning incense in the middle of the arena near the bamboo chicken cage with its thin cloth cover. The incense was put in a very simple earthenware while the simple bamboo chicken cage was covered with a simple, plain, thin, yellowish orange cloth. The simplicity of the equipment used indicates the mediocre economic condition of the group.

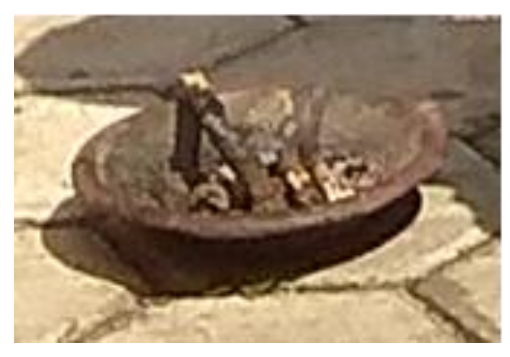

Image 2. The burning incense

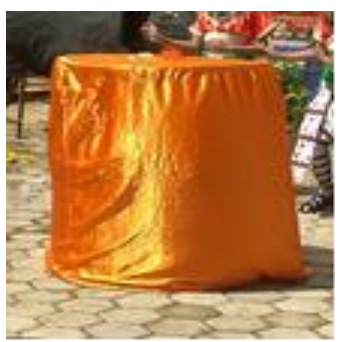

Image 3. The bamboo chicken cage

(Team document: Linggo Asri village, Pekalongan, June 23rd, 2018)

Also at this phase the Sintren dancer entered the open arena accompanied by four escort dancers. The number of the escort dancers has certain meaning. It refers to the forty nymphs in many Javanese folklore that descend to the earth on certain occasions ("Sintren 2" n.d.). These four escort dancers flanked the Sintren dancer who was still wearing ordinary clothes. The five dancers were dancing while circling the arena. It can be assumed that the purpose is to make the coming show livelier and to persuade more audience to gather around the informal arena.

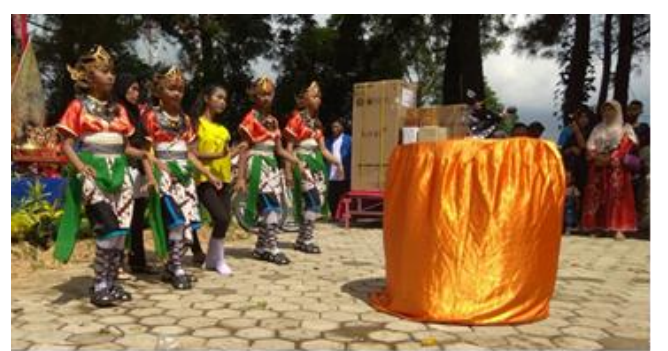

Image 4. Sintren dancer (wearing yellow and black clothes) was dancing in the middle of four escort dancers

(Team document: Linggo Asri village, Pekalongan, June 23rd, 2018)

\section{The Third Phase of Sintren as a Folk Art}

The third phase of Sintren was the main show. It was the most awaited attraction. This essential phase was divided into three awesome sessions as will be described briefly but in details. 


\section{a. The First Session of the Third Phase}

At this phase, Sintren shaman while holding his kris was chanting the incantation in front of the burning incense. The shaman was partly wearing traditional Javanese clothes: batik shirt and blangkon lurik (headdress with traditional motif) with dark trousers. Again, the simple clothes indicate the mediocre economic condition of the group. The shaman was not wearing a complete Javanese costume for male consisting of jarik (cloth with traditional motif used to cover the low body part as a substitute for trousers), beskap (Javanese traditional clothes like a coat), and iket/blangkon (Javanese headband) in a similar Javanese motif such as batik or lurik. The kris held by the shaman also did not have an expensive appearance. All these, again, indicate that the shaman and the group are limited in financial support. Even though in minimalist look, the magical atmosphere was successfully built in the arena at that time.

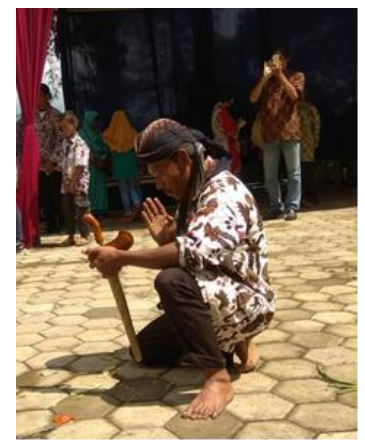

Image 5. The shaman was chanting the incantation

(Team document: Linggo Asri village, Pekalongan, June 23rd, 2018)

After the serious and incessant chanting of the incantation by the shaman, the Sintren dancer who was always attended by two female adults started to be in "in trance" condition. While being in "in trance" condition, the Sintren dancer's both hands were tied by the shaman and then she was carefully placed inside the prepared bamboo chicken cage already covered in thin cloth. The following sequential images illustrate the description.
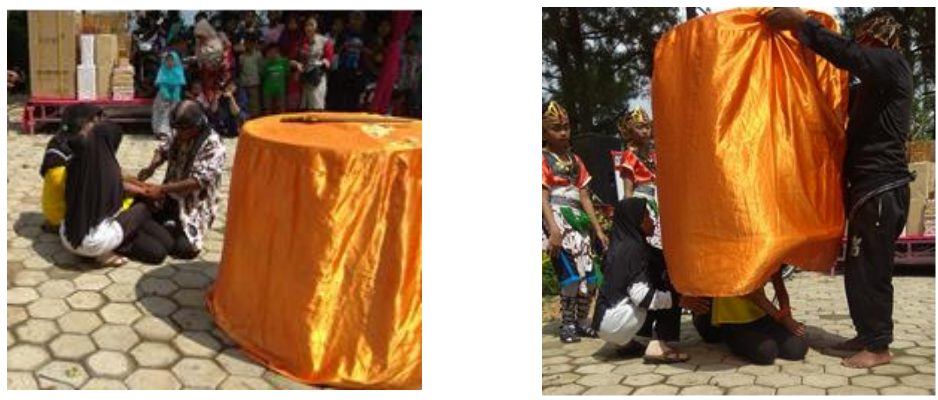

Image 6. The Sintren shaman was tying both hands of the Sintren dancer Image 7. The Sintren dancer, in trance with both hands tied, was put inside the bamboo chicken cage

(Team document: Linggo Asri village, Pekalongan, June 23rd, 2018)

While the Sintren dancer was inside the bamboo chicken cage, the shaman kept chanting the incantation while waiting for the transformation. The bamboo chicken cage would shake as if something was moving inside when the transformation has taken place. This was the unique sign waited by all people around the bamboo chicken cage. The shaman would hurry up towards the bamboo chicken cage. 


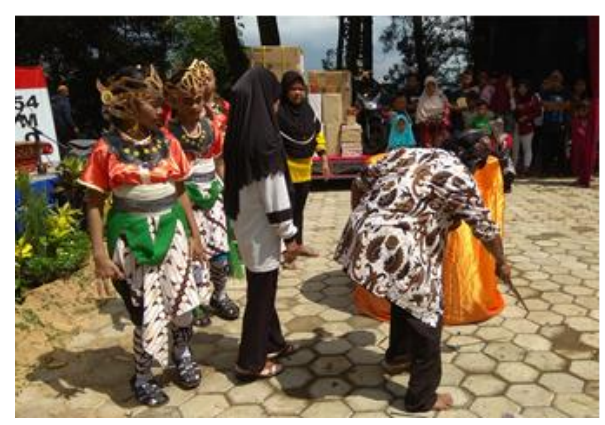

Image 8 . The Sintren shaman, holding a kris was circling the bamboo chicken cage while enchanting the incantation

(Team document: Linggo Asri village, Pekalongan, June 23rd, 2018)

After the shaking bamboo chicken cage was opened, the Sintren dancer was taken out of it. The Sintren dancer had changed into a light yellow and batik dancing costume equipped with a long red shawl cloth for dancing, a headdress with flower veil, and a pair of black spectacles. However, both of her hands were still tied. She was in a weak condition and still in trance. The shaman opened the tie around her hands and his incantation gave strength to the Sintren dancer to stand up. The dancing costume worn by the Sintren dancer of Kudo Bekso Utomo group is very simple and not expensive but colorful enough. Whatever the modification of the dancing costume, three things must be included. The first is the head-dress with its flower veil which the writer assumes as a symbol of crown usually worn by a princess. The second is the black spectacles which are said to cover the closed eyes of the Sintren dancer who is in "in trance" condition (Isnaeni 2012). The third is the long white socks which maybe symbolize the purity and giving the sense that the Sintren dancer is not touching the earth. She is like a nymph floating while dancing attractively around the open arena.

While the Sintren dancer was dancing, the audience threw saweran (money given voluntarily). There is a strict rule here that the money is given by throwing it around the dancing Sintren. The thrown money should not touch the Sintren dancer. The audience is also not allowed to approach and touch the Sintren dancer while doing saweran because the Sintren dancer will faint since the spirit will leave her abruptly. By not approaching or touching the Sintren dancer, the immoral acts or intended harassments are prevented. The purity of the Sintren dancer is intact.

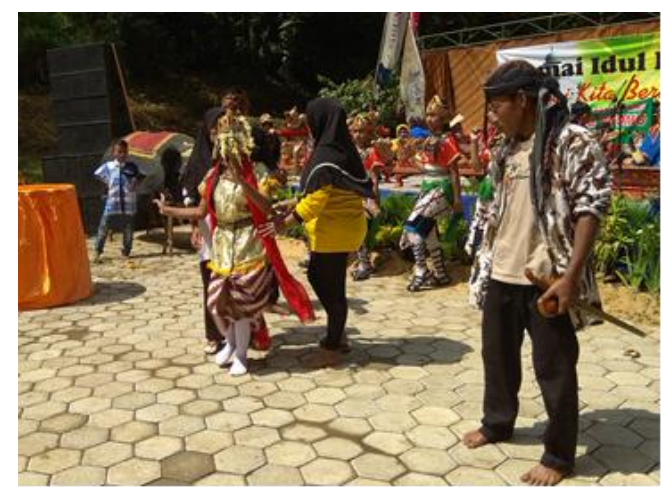

Image 9. The Sintren dancer was dancing in her new costume (light yellow dancing costume and headdress with white flowers)

(Team document: Linggo Asri village, Pekalongan, June 23rd, 2018) 


\section{b. The Second Session of the Third Phase}

The second session of the third phase happened when the Sintren dancer lost her energy. Then the Sintren dancer's both hands were tied again, this time it was done by one of the members of the research team. The purpose of this participatory action is to prove that the knot is tight and it will not change after the changing costume process. After that the Sintren dancer was placed inside the bamboo chicken cage again, and the shaman was chanting the incantation again. The following images capture the steps.
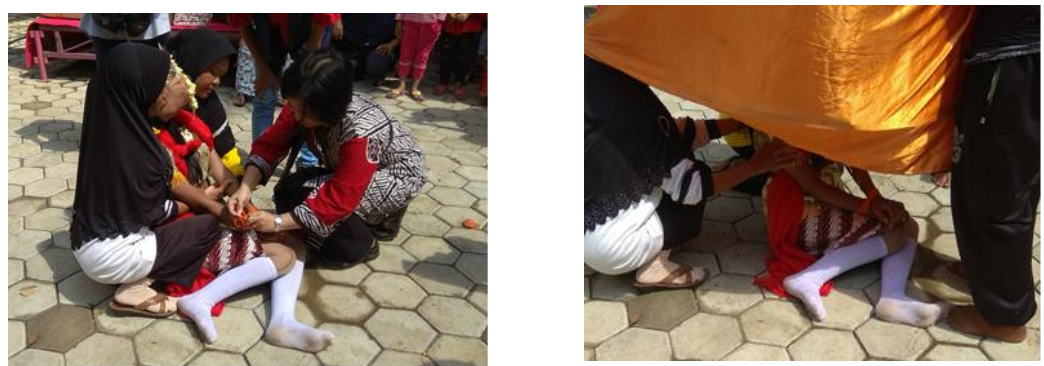

Image 10. One of the research team's members was tying both hands of the Sintren dancer Image 11. The Sintren dancer in her light yellow costume with both hands tied was again placed inside the bamboo chicken cage covered with orange cloth

(Team document: Linggo Asri village, Pekalongan, June 23rd, 2018)

After the bamboo chicken cage was shaking, it was lifted and the Sintren dancer had changed into another different dancing costume, a red one, still equipped with the red long shawl cloth, the headdress with its flower veil, and the black spectacles with both of her hands still tied in the same knot as before. The shaman opened the tie and helped the Sintren dancer to stand up with his incantation. Finally, the Sintren dancer was dancing lively again in her red dancing costume. The following series of images show the crucial steps of the changes.
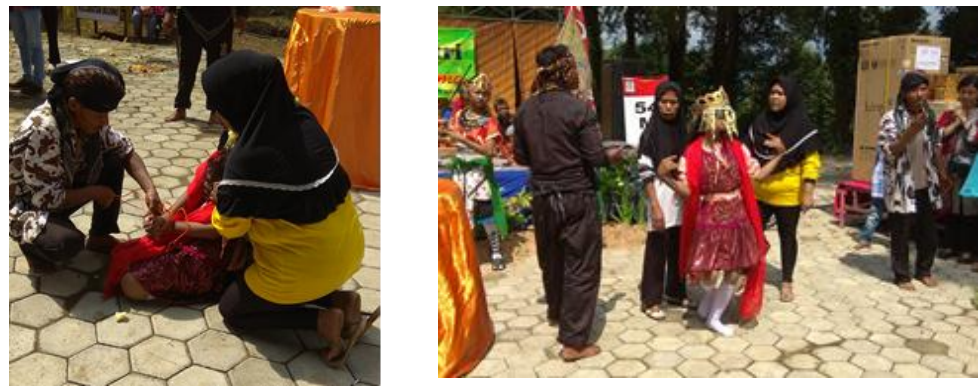

Image 12. The Sintren shaman was untying the ties still binding both hands of the Sintren dancer Image 13. The Sintren dancer began to dance in her new red dancing costume with the same headdress (Team document: Linggo Asri village, Pekalongan, June 23rd, 2018)

For the second session of the third phase, the audience threw saweran again as the Sintren dancer was dancing circling the arena. The money collected from the saweran session will become the income of the group. If the audience feel satisfied with the performance, the group can get more money from the saweran. Based on the researcher's observation, the more magical the situation is, the more money is thrown by the enchanted audience. The magical situation is also supported by the gamelan music.

\section{c. The Third Session of the Third Phase}

The third and last session of the third phase had the same sequence as the previous two. The Sintren dancer got weak as a sign to enter the next session of changing dancing costume. Again, the Sintren 
dancer was tied with a long rope, only this time the leader of the research team participated in tying both hands of the Sintren dancer. Again, the purpose of this participatory action is to prove that another different but still intricate knot is tight enough and later it will remain the same. After the Sintren dancer was placed inside the bamboo chicken cage, she changed her dancing costume into the blue one. The still weak Sintren dancer was helped by the shaman and then she danced lively again. Again, the audience threw saweran around the dancing Sintren without approaching or touching the Sintren dancer. The following sequential images tries to represent the important moments.
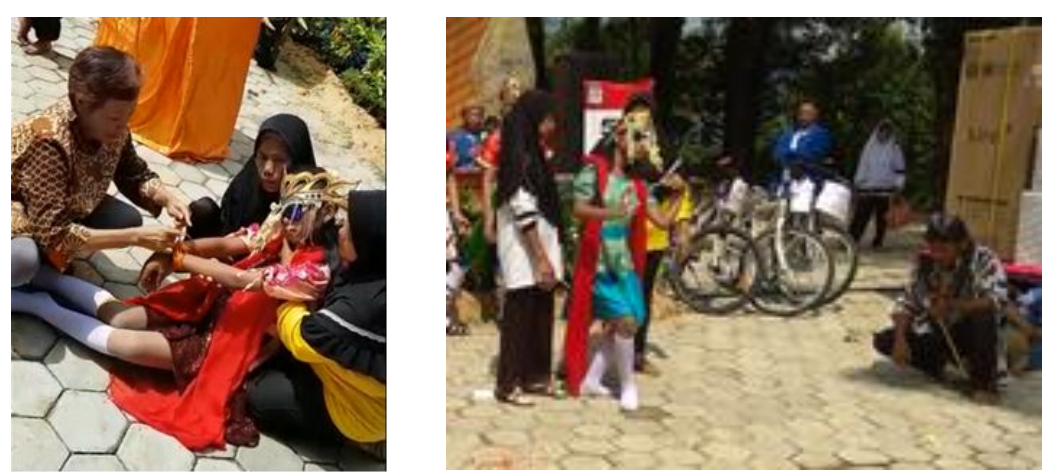

Image 14. The research team's leader participated by tying both hands of the Sintren dancer

Image 15. The Sintren dancer was dancing in her blue dancing costume

(Team document: Linggo Asri village, Pekalongan, June 23rd, 2018)

\section{The Closing Phase of Sintren as a Folk Art}

The closing phase of Sintren as a folk art was again signed by the Sintren dancer who got weak. Then she was placed inside the bamboo chicken cage and after a while the bamboo chicken cage was lifted and she had changed into her ordinary clothes that she wore before. The Sintren shaman helped the Sintren dancer to wake up from her "in trance" condition. The Sintren show was over and the writer as the leader of the research team had a chance to continue the interview with the Sintren shaman and his assistant. The following four pictures capture the important moments.
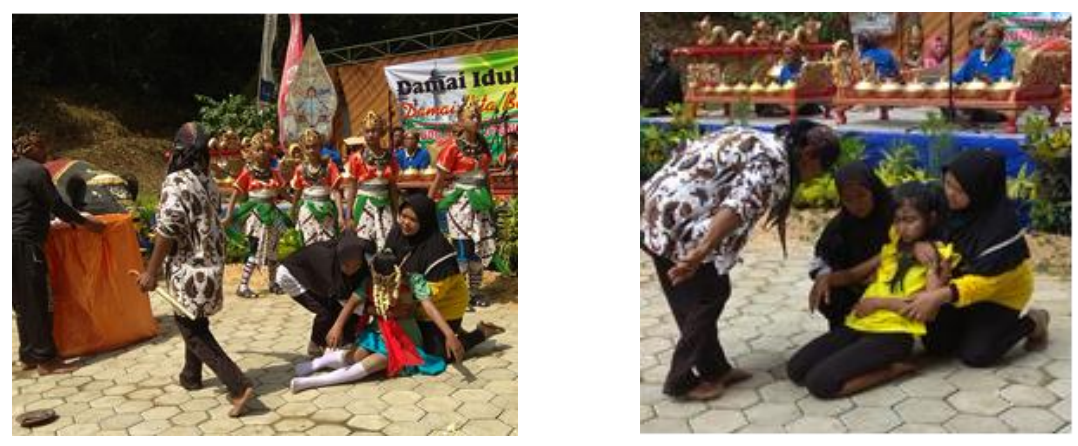

Image 16. The weak Sintren dancer was going to be placed inside the bamboo chicken cage again

Image 17. The Sintren shaman was waking up the Sintren dancer

(had changed into her previous ordinary clothes) from her trance

(Team document: Linggo Asri village, Pekalongan, June 23rd, 2018)

\section{Sintren as a Magical Performance}

The Sintren folk art show as described verbally and portrayed in various images in the previous subheading discussion can be categorized as a performance because it indicates several features of 
performance. The staging or performance-ness is so thick or it is called "theatricality" by Ben Amos. First, there are performers. The main performers are the Sintren shaman (and his assistant) and the Sintren dancer. The supporting performers are the four escort dancers, the two female adults attending the Sintren dancer, the gamelan crew and singers. Second, there is "front," borrowing Goffman's term. It is in the form of the stage, the gamelan set, and the bamboo chicken cage with its thin cloth cover. Third, there are what Goffman calls "appearance and manner." It is represented mainly by the Sintren shaman. His "appearance and manner" are thick with magical aura. His traditional Javanese clothes, his gestures, his expressions, and his actions are all creating the magical atmosphere. Fourth, there is specific Javanese paraphernalia used to developing the magical situation of the performance; namely kris, burning incense, incantation. Fifth, in line with Goffman's opinion, the Sintren shaman as the essential performer truly believes that the folk art show is magic and he can influence the audience that the performance is magic.

The Sintren folk art show is not a trick. There are several reasons why it cannot be classified as just a trick. First, it is done in an open and broad day light. There is no modern equipment to support a trick. No angle is hidden from the audience. The audience can see the show from whatever angle and position. Second, the bamboo chicken cage, an essential equipment in the show, is not so big. It is just enough for a person to be inside it in a sitting position. There is no secret compartment inside the bamboo chicken cage to hide the changing clothes and to keep the previous clothes. Third, the thin cloth cover is very simple with no folded parts and it is also almost transparent. It cannot cover the trick if there is a trick inside the bamboo chicken cage. Fourth, the Sintren dancer is placed inside the bamboo chicken cage with both hands tied intricately. This and the fact that the space inside the bamboo chicken cage is not wide make it impossible for the Sintren dancer to change into dancing costume as what the ordinary person does in the changing room. The Sintren dancer, if not in magic influence, needs both hands free to put off the previous clothes and to put on the new costume. The fact that her both hands are still tied as before after the bamboo chicken cage is lifted refers to the power of magic. So, the Sintren performance is a magic performance. Some points also support the magic side of the Sintren performance. The Sintren dancer is always "in trance" during the performance. She will be in a weak condition if the spirit leaves her body. The Sintren shaman chants the incantation to make the spirit enter the Sintren dancer again.

The whole magical element of Pekalongan Sintren is related to the functions of this traditional folk art. According to the folklore of the forbidden love between Sulandono and Sulasih, its function is to meet the two lovers magically in every ritual event of village cleaning (bersih desa). Based on this folklore, Pekalongan Sintren is performed in periodic rituals such as earth sacrifice (sedekah bumi), sea sacrifice (sedekah laut), avoiding plague (tolak bala), realizing holy promise (nadzar), and avoiding unlucky happening (ruwatan). Pekalongan Sintren is also performed in marriage parties and other ceremonies("Sintren 2" n.d.). In short, its magical element is the essence of the Sintren performance and functions.

\section{CONCLUSION}

Pekalongan Sintren folk art is a unique performance which is not a trick but full of magic. Although it is performed informally in an open space, the "theatricality" of the show is strongly felt by the audience. The stage with the gamelan set, gamelan music, crew, singers, and the female escort dancers act as a warming-up before the main magic entertainment is performed. The Sintren shaman with his traditional Javanese clothes, kris, and burning incense builds a magical atmosphere. The bamboo chicken cage covered in this cloth creates a magical mystery. The Sintren dancer-in trance, with both hands tied with a long rope and placed inside bamboo chicken cage but can change into several 
dancing costumes-is totally enigmatic. No hidden angles, no modern equipment helping the performance, and no limited access to see the performance support the conclusion that Pekalongan Sintren folk art is a magic performance not a trick at all.

Meanwhile, as presented and discussed in details, the survival strategies applied by the regional arts group "Kudo Bekso Utomo" can be observed during the performance. The simplicity of the magical paraphernalia (the simple earthenware for the incense, the simple bamboo chicken cage and its simple and plain cloth cover), the simple costumes of the Sintren dancer, the shaman, and his assistant, and the ordinary clothes of the two adult females accompanying the Sintren dancer indicate the limited financial power of the group. However the group still keeps preserving the traditional magical performance often marginalized in the modern era by always present in local events whether invited or not. The breakthrough done by this group is in the form of presenting a non-virgin Sintren dancer to circumvent the difficulty of finding a young virgin female to become a magical Sintren dancer. All these strategies must be appreciated.

\section{ACKNOWLEDGMENT}

This work was part of the field research financed by the DIPA of Faculty of Humanities, Diponegoro University, 2018 fiscal year.

\section{REFERENCES}

Aditama, L.D. 2016. "Kesenian Sintren sebagai Kearifan Lokal Ditinjau dari Metafisika Anton Bakker." Humaniora 21 (1):57-72.

Aldila, N. 2017. "Kesenian Tradisional Masih Minim Perhatian Pemerintah," https://lifestyle.bisnis.com/read/20170419/230/646230/kesenian-tradisional-masih-minimperhatian-pemerintah.

Asdhiana, I.M. 2014. "Gemulai Sintren di Pesisir Pekalongan." https://travel.kompas. $\mathrm{com} / \mathrm{read} / 2014 / 10 / 23 / 154000527 /$ Gemulai.Sintren.di.Pesisir.Pekalongan?page=all.

Asyari, Y. 2017. "Sintren, Tarian Mistis yang Semakin Dilupakan." https://www.jawapos. com/artspace/seni-tari/06/08/2017/sintren-tarian-mistis-yang-semakin-dilupakan/

Baker, W.E. and Ronald Inglehart. (2000). "Modernization, Cultural Change, and the Persistence of Traditional Values." American Sociological Review 65:19-51.

Ben-Amos, D. 1997. No Title. In Folklore: An Encyclopedia of Beliefs, Customs, Tales, Music, and Art, edited by T.A. Green. Santa Barbara, California: ABC-CLIO, Inc.

Bro, G. 2016. "Mencari Jejak Sintren, Kesenian Rakyat Asli Pekalongan yang Telah Punah." https://www.pekalongan-news.com/2016/01/mencari-jejak-sintren-kese-nian-rakyat.html

Bronner, S. J. 2007. The Meaning of Folklore: The Analytical Essays of Alan Dundes. Logan, Utah: Utah State University Press.

Dundes, A. 1965. The Study of Folklore. Upper Saddle River, NJ: Prentice Hall.

Goffman, E. 1956. The Representation of Self in Everyday Life. Edinburgh: The University of Edinburgh. 


\section{Social Science Research Centre.}

Irianto, A.M. 2017. "Kesenian Tradisional sebagai Sarana Strategi Kebudayaan di Tengah Determinasi Teknologi Komunikasi." Nusa: Jurnal Bahasa dan Sastra 12 (1):90-100.

Isnaeni, D. 2012. "Kesenian Sintren, Lestarikan atau Tidak?" http://kebudayaankesenianindonesia.blogspot.com/2012/05/kalau-bukan-kita-siapa-lagi-yangbisa.html.

Jones, M. (n.d.). "What is Trance?" http://www.cuyamungueinstitute.com/articles-and-news/what-istrance/.

Kynth. 2007. "shaman." https://www.urbandictionary.com/define.php?term=shaman.

"magic-trick." n.d. "magic-trick." http://www.yourdictionary.com/magic-trick.

"Magic vs Trick." n.d. "Magic vs Trick - What's the difference?" https://wikidiff.com/ magic/trick.

McCormick, C. 1997. "Participant-Observation Method." In Folklore: An Encyclopedia of Beliefs, Customs, Tales, Music, and Art, edited by T.A. Green. Santa Barbara, California: ABC-CLIO, Inc.

O’Connor, K.M. 1997. "Participant-Observation Method." In Folklore: An Encyclopedia of Beliefs, Customs, Tales, Music, and Art, edited by T.A. Green. Santa Barbara, California: ABC-CLIO, Inc.

Pentikäinen, J. 1997. "Shamanism." In Folklore: An Encyclopedia of Beliefs, Customs, Tales, Music, and Art, edited by T.A. Green. Santa Barbara, California: ABC-CLIO, Inc.

"Rahasia Mistis Tari Sintren." (2015). "Rahasia Mistis Tari Sintren." https:// pusakadunia.com/blog/rahasia-mistis-tari-sintren/.

Ribkha, M. n.d. "Kisah Asal-Usul Kesenian Sintren Pekalongan." https:// www.cintapekalongan.com/kisah-asal-usul-kesenian-sintren-pekalongan/.

Saputra, A. 2015. "Kontinuitas, Perubahan, dan Kritik Sosial dalam Kesenian Wayang Hip Hop." https://www.kompasiana.com/andi_saputra17/ 56228819cd9273560c05c988/kontinuitasperubahan-dan-kritik-sosial-dalam-kesenian-wayang-hip-hop

"Sintren 2." n.d. "Sintren 2." https://pandoe.rumahseni2.net/nusantara/sunda/sintren/.

"Trick." $\quad$ n.d. "Trick." https://www.google.com/search?source=hp\&ei= IIjnW6OwKYrhvgTu6YC4\%0ACQ\&q=what $+{ }^{+i s}+\mathrm{a}+$ trick\%3F\&oq $=$ what $+{ }^{+}{ }^{+}+\mathrm{a}+$ trick\%3F\&gs_l= psy-\%0Aab.3..0i19k1110.2269.8161.0.8584.16.16.0.0.0.0.100.1233.

15j1.16.0.......1.1.\%0A64.psy-ab..0.16.1225...0j0i131k1j0i22i30k1.0.XETKxQ 